\title{
Diffusing Entrepreneurial Innovation And Tourism: An Empirical Evidence of Permaculture
}

\author{
Umeh Azubuike Lucky ${ }^{1 *}$, Leilani I. De Guzman ${ }^{2}$ \\ ${ }^{12}$ Saint Louis University, Baguio City, Benguet 2600, Philippines
}

\begin{abstract}
A B S T R A C T
Entrepreneurial innovation and tourism are essential factors in the economic growth of a rural agrarian area. This paper's concept is from Schumpeterian creative destructions' philosophical idea to shift rural communities' mentality from the product-based economy to diverse tourism entrepreneurship. In achieving and sustaining the development of permaculture as a platform for rural agritourism, the social capital theory of collectivism was employed to foster the development that would deliver socio-cultural, environmental, and economic benefits to all stakeholders in the community. This paper employed a descriptive research design to analyze the diffusion of entrepreneurial innovation and tourism systematically; also, to interpret the community's attitude towards the diffusion of permaculture for agritourism.
\end{abstract}

Furthermore, interviews were conducted with the key informant group among the women organization. The paper subjected its participants' through a non-probability sampling method using cluster sampling in the three barangays of the municipality of Bokod, Province of Benguet. The study results show that the respondents were willing to accept the permaculture for tourism and were willing to commit time to develop and manage the Permaculture project. They were motivated to accept and to participate in the project because they knew the values and benefits that permaculture would bring to the community. Also, while answering contingency valuation questions, the respondent thought about the value and benefits the project would bring. This study will enable communities to develop agritourism through permaculture landscapes in the rural community and, help policymakers in planning sustainable projects to support the community in entrepreneurial innovation.

\section{A R T I C LE IN F O}

Article History:

Received : 26-03-2021

Revised : 23-05-2021

Accepted : 03-06-2021

Published : 30-06-2021

Keywords:

Entrepreneurial Innovation

Agritourism

Orphan Crops

Permaculture

Social Capital.

JEL: M13, M21, M10

*Corresponding Author E-mail:

umehazubuikelucky@gmail.com 


\section{INTRODUCTION}

Innovation and entrepreneurship are essential accelerators and significant factors for longterm economic growth that happens through replacing old concepts with new ideas known as creative destruction or innovation that can be incremental or disruptive (Hjalager, 2014; $\mathrm{Li}$, \& Huang, 2019). Such is made possible by an entrepreneur who transforms factors of production and social capital to create value for society (McDaniel, 2010).

Successful entrepreneurs depend on the information they possess about their environment. They need to know economic, social, political, and environmental changes to proffer creative solutions in tackling the pressing problems and needs as well as the trends in demographics, perception, mood, and meaning (Pérez, 2015). Likewise, they examine what is happening outside the industry to create new products or have new ideas on solving existing problems. They find opportunities to innovate beyond the industry and market structures resulting to the entrepreneurial innovation. Entreprneurial innovation generates attention because of the expansion of its concept in sustainability, social, and institutional entrepreneurship (Ramírez et al., 2019). To this, Schumpeter explained that the capitalist social institution provides endless sources of new ideas that result in successful innovation, which entrepreneurs use to create market opportunities through the essential changes in lifestyle, structure, and production. In Schumpeter's theory, the innovations and the change in economic systems are done by entrepreneurs as sources of innovation (McDaniel, 2010). Fagerberg et al. (2006) added that the society and organization's competitiveness is strongly dependent on their tendency to think and practice new and reformed ways of doing things, which is an innovation act.

According to Śledzik (2013), Schumpeter's teachings have become of utmost importance concerning the world economy's present situation, in particular this modern-day crisis (Covid-19) that resulted in the weakening of economic strength due to the pandemic's devastating impact. Most businesses, mainly in the tourism sector, have been put to a halt due to social distancing, travel restrictions, and government policies to control the virus's spread. Most countries have also experienced economic erosion due to the coronavirus pandemic. Śledzik (2013) suggested that for countries to survive the post-crisis era, they should become entrepreneurial. They must support entrepreneurs who introduce innovations in the economic system. Such an economy necessitates dynamic technological progress that will evolve around neo-Schumpeterian economic principles requiring an increased understanding of entrepreneurial innovation diffusion.

\section{The Research Objective}

Based on the literature review, the study intended to analyze the diffusion of entrepreneurial innovation and tourism systematically. This was done by exploring permaculture as an alternative agricultural system that characterizes an entrepreneurial innovation. To elaborate on the diffusion of entrepreneurial innovation, an investigation on the Willingness to Accept (WTA) and Willingness to Commit Time (WTCT) in the permaculture project was undertaken. Hence, to be able to integrate permaculture into agritourism through innovation and entrepreneurship, the following questions were addressed:

1. Are there significant differences in the Willingness to Accept the permaculture project to diffuse entrepreneurial innovation and agritourism?

2. Are there significant differences in the willingness to Commit Time in developing the Permaculture project to diffuse entrepreneurial innovation and agritourism?

\section{The Rationale of the study}

Bokod terrain is prone to landslides and other environmental issues in practice. The entrepreneurial innovation (permaculture) would help to mitigate environmental degradation and 
other environmental issues in the region, as well as serve as a useful platform for the community's agritourism development. This paper aims to disseminate agritourism as a missing market in the community, disrupting the status quo.

\section{Hypotheses}

Hereby, the following hypotheses were presented

1. There are no significant differences in the Willingness to Accept the permaculture project.

2. There are no significant differences in the Willingness to Commit Time in the permaculture project.

3. There is a significant relationship between the Willingness to Accept in terms of the (a) socio-demographics and the (b) social capital elements.

4. There is a significant relationship between the Willingness to Commit Time in terms of the (a) socio-demographics and the (b) social capital elements.

\section{LITERATURE REVIEW}

Schumpeter being among the first to discuss entrepreneurship's concept, believed that the economy needs innovation by entrepreneurs because it makes the old way of doing things obsolete. He focused on how entrepreneurs create and destroy the old ways of doing things, causing creative destruction in the economy. In Schumpeter's (1942) words, creative destruction brings continuous progress in the economy and improves people's wellbeing by raising the standard of living in society. In essence, creative destruction brings economic development within any society's economy as the driving force of an area's economy (Bostaph, 2013). The theory of innovation by Schumpeter (1939) enables entrepreneurs as agents of creative destruction to advance innovation via new sets of production functions, new products, a new group of organizations, and a new market that increases the demand for the product.

This new idea or knowledge comes from studying the economic changes that have occurred in the industry. Consequently, entrepreneurial innovation occurs due to unexploited and potentially valuable gaps between complementary goods or technologies (Carden, 2011).

The entrepreneurial innovations are measured by capitalism through profits gained, as in Peter Drucker's words; profits are a source of regeneration, moral, and ethical system. While in the social sector, entrepreneurial innovations are measured by human productivity to society and organization, it contributed effectively to an organization's function, which is the ability to maintain continuity in change (Linkletter \& Maciariello, 2009).

Entrepreneurial innovation is an integral part of the tourism economy. It sustains tourism growth and increases tourism activity fields serving as the driving force of tourist attraction. Entrepreneurial innovation in tourism is not only the mere profit-oriented logic but also the expression of a culture-oriented attitude (Silvestrelli, 2012). It helps the agrarian community to develop sustainable tourism destinations that will foster economic development in rural areas. It creates entrepreneurial activities that help farmers and practitioners through training and support in diversifying their agricultural activities (Stanovčić et al., 2018) that also bring a remarkable change in their way of thinking and hospitality training. Stojanović (2018) claims that entrepreneurial innovation plays a significant role in tourism development as it increases the number of new visitors and tourist traffic, facilitates community network that will provide means for sustainable livelihoods in tourism (Kokkranikal \& Morrison, 2011), and enhances the cultural tourism of the area making the tourist experience fulfilling and sustainable (Silvestrelli, 2012). Tourism is one of the tools for rural area development.

This strategy has the potential for job creation, the potential to increase the source of income for a farm-based livelihood, and the potential to conserve the environment and the agricultural 
heritage landscape. According Swart and Orsmond (2010) they found agritourism as a new agricultural industry idea. Agritourism is considered a viable alternative for rural areas' present and future progress (Drăgoi et al., 2017). Siemens (2007) believed that this form of tourism will help revive the rural economy and improve its infrastructure. Swart and Orsmond (2010) said that agritourism provides new opportunities for work, education, and how the agricultural industry should be. Agritourism is an emerging entrepreneurial innovation that can protect farming incomes against market fluctuation (Chiang et al., 2017).

Jegdic et al. (2017) stated that the local community, social and political institutions, and individuals can manage their rural tourism to create proviso and facilitate entrepreneurial activities to enhance tourism development. The aim will be to satisfy the tourist's needs and ensure the local community's sustainable development. To have effective and efficient development of tourism in the rural community requires cooperation and partnerships of all stakeholders and significant investment in entrepreneurial projects that are under modern market trends (Jegdic et al., 2017)

To encourage tourism influx in the rural area, the community needs to support mainly the development of entrepreneurship tailored for tourism (Surugiu, 2009). Xuhua et al. (2018) claimed that entrepreneurial activities enhance business ventures' patronage and sustainability in the tourism sector. For rural agritourism to be successful, it requires the local government and community cooperation to give attention to entrepreneurial innovations.

Tourists are fascinated with innovative experiences, which can increase repeated visits and patronage. Though entrepreneurial innovations are leveraging on the natural resources and cultural heritage, the development of desirable tourist destinations is an opportunity worthwhile to pursue. It can promote the rural tourism experiences that are not available to urban dwellers (Stolarick et al., 2010). Moreover, entrepreneurial innovation can strengthen the local brand and increase local identity (Siemens, 2007). Rural agritourism is deemed viable in areas where the landscape has enormous growth and development potentials. In the Cordilleras' mountainous landscape, the Province of Benguet is ideal for agriculture due to its environment and climate. The place boasts of its abundant flora and fauna because of its endowment in forested and agricultural lands enabling the community to produce a diversity of edible wild fruits (Chua-Barcelo, 2014) and orphan crops.

Orphan crops were defined by Assefa (2014) as the less researched and underfunded crops due to their lesser importance in the global market. These crops are resilient and adaptive to environmental stress and provide an indispensable source of staple food to the vast majority of less privileged farming communities. The orphan crops include the following: root crops, cereals, vegetables, fiber crops, fodder crops, legumes, oil crops, and medicinal plants, which predominantly found in Asia, Africa, and Latin America (Assefa, 2014; Tadele, 2019; Caselli-Mechael 2015; Malik \& Chaudhary 2018). Orphan crops are highly nutritious tuber crops with the right vitamins, micronutrients, and starch content that meet human needs and fight hidden hunger (Naluwairo, 2011). According to Malik and Chaudhary (2018), in the country where orphan crops are grown, they consider orphan crops their major staple food that provides sustenance and nourishment to the less privileged. It also contributes to global poverty reduction as an income and livelihood source to the poor farmers in society (Tadele, 2019). They categorized these orphan crops as locally abundant grown crops in developing countries that are not trading internationally. Scientific information or knowledge about them is insufficient and has relatively low economic potential (Gruère et al., 2006). Based on America's crop science society, statistics show that 12,650 edible plant species exist, and $95 \%$ of the world population only utilized 30 of them. Orphan 
crops are more adapted and more acclimatized to innumerable abiotic stress than the world's main crops.

The orphan crop definitions vary, but they all highlight one aspect: orphan crops have potential and are not fully explored. Despite their essential role, they receive limited attention from the global scientific community (Tadele, 2019; CaselliMechael 2015). Orphan crops have not gained the attention needed; even researchers and scientists who work on these crops have been marginalized, hampering the work on orphan crop literature (Assefa, 2014).

They further stated how to properly plan and manage these orphan crops with organic farming to optimize the soil nutrient. These practices focused on the right combination of crops suitable for the area, soil health, and fertility that suit each crop, knowing that plants' nutrient requirements differ. Catholic Relief Services (2008) released a manual on homestead gardening, which is a compilation of best practices that successfully help farmers in improving their food production, nutrition, food security, livelihood, and income generation through organic farming and permaculture principles, which could reduce the environmental hazards from conventional farming practices within the Province of Benguet.

Permaculture is a human settlement design that focuses on a sustainable agricultural system (Holmgren, 2002) that restores degraded landscapes by making farmland less vulnerable to climate change. Through permaculture, orphan crops abundantly growing wild in the Province of Benguet can be cultivated and managed. A permaculture is a promising approach because human beings have to conserve the environment for the next generations (Akhtar et al., 2014). It is a concept for changing one's way of living and interacting with nature. It provides a more functional ethic and value-based system that renders a newer eco-centric definition for sustainable management. The permaculture approach integrates the social, economic, and ecological values and ethics to gain sustainability. A permaculture landscape is a sustainable system that provides all the needs of its inhabitants whose design involves detailed research into which plants are native or well-adapted to the local area, offering not only practical benefits but also aesthetic satisfaction for tourism attraction.

Permaculture is more of a culture, not just agriculture. It's more of a way of life because the design is a self-contained and self-sustained human settlement in the post petrol world. It reduces environmental degradation and pollution caused by industrial technologies in agriculture (Morel et al., 2018). Permaculture can support livelihood activities and enhance farmers' ability to handle environmental problems (Didarali, \& Gambiza, 2019). These are related to what orphan crops contribute to the environment and the farmers who cultivate them (Tadele, 2019; Mwendwa, 2019).

According to Schmidt (2016), it is an alternative way of living and thriving, a cultural shift from the neoliberal economy. Birnbaum and Fox (2014) stated how a barren land, a chemically destroyed farmland, or an extreme drought area could be rehabilitated into an ecological haven of plant and wildlife using permaculture.

Pretty et al. (2011) suggested the new agricultural system can foster new social infrastructure and cultural relations to emerge new businesses that will drive local economic growth and ultimately improve rural communities' wellbeing. Now, there is an emerging need to explore new approaches in the direction of balancing ecological and economic returns, which has attracted the attention of the global business community because the integration of permaculture philosophy in business strategy has the potential to achieve sustainability (Akhtar et al., 2015).

Permaculture provides a comprehensive perspective on agriculture that enhances and strengthens biodiversity, promoting 
agritourism (Vella, 2010). According to Worldwatch institute (2001), $10 \%$ to $20 \%$ of the world's farmland suffers from some level of degradation that reduces food production by $13 \%$ due to hi-tech agriculture. The increase in farmland degradation shows a need to move away from industrial agriculture that harms the environment to new agriculture methods that will create sustainable development. Madeley (2002) claimed that the new agriculture approach would provide food for all. It will enable farmers to shift to the organic method of farming, such as permaculture. It will bring out the community's cultural heritage, tackle the issue of hidden hunger and environmental degradation, and provide aesthetic satisfaction (Assenza 2016). Permaculture will enhance tourism attraction (Holstein, 2013) and also engage farmers in agritourism. Schilling and Sullivan (2014) found that farms practicing organic production methods and farm conservation have higher significance to venture into agritourism.

Permaculture is considered in the study as an entrepreneurial innovation that highlights an alternative agricultural system. Permaculture not only presents an aesthetic and innovative farming approach but also serves as a source of leisure that contributes to local economies through tourism. Some permaculture gardens in the urban place were seen as places to meet, socialize, work, and learn. Most permaculture sites like the Springfield community garden in Leeds provide a communal kitchen for tourists and neighbors to process food from the garden (Howe \& Wheeler, 1999). As an entrepreneurial innovation, permaculture can enhance agritourism by attracting visitors to the rural agricultural area to entertain and educate tourists and generate income for the farm (Barbieri \& Mshenga, 2008; Ollenburg \& Buckley, 2007).

An example of permaculture settlement is the Chikukwa permaculture village in Zimbabwe. Its landscape gives the garden a unique look resembling the Garden of Eden. Permaculture provides cultural capital in scientific knowledge and encourages community participation, social interactions, and knowledge sharing in sustaining the project as it depends on communitybased learning (Chiromo \& Kazembe 2016). It enhances agritourism by providing education to tourists and students in agriculture and permaculture (Eurac Research, 2018). Polyface Farms in Swoope, Virginia, is another example of a permaculture farm using innovation to draw visitors through its information about the area's food, culture, and history (Wolfe, 2019).

According to Schmidt (2016), Birnbaum and Fox (2014) have shown what permaculture is and what it can be, stating that permaculture is a series of principles, not just rules or actions. There is literature evidence that the scope of permaculture is beyond agriculture practices. It is permanent agriculture and permanent culture (Permatil, 2006; Schmidt, 2016). Vitari and David (2017) suggested that permaculture concepts and principles are potential alternatives that could help innovative management models to attain sustainability.

Stephens (2013) suggested that incorporating the environment within one's action is a guide to move on because one foresees a larger scale of destruction on the ecosystem in the future. Permaculture helps control the deficient conventional methods, which are unsustainable in business management by its ethical codes, enhancing effective and efficient environmental, social management, and sustained economic success (Akhtar et al., 2015). Moreover, permaculture is a system designed to provide an integrated sustainability management approach that incorporates ecological/environmental, economic, and social aspects.

Based on the Schumpeterian theory of innovation, permaculture is considered an entrepreneurial innovation. It brings continuous progress in the economy and improves people's wellbeing by raising the standard of living in society. It reduces environmental degradation and pollution caused by industrial agriculture. As an entrepreneurial innovation, permaculture 
practices will be used to cultivate orphan crops, to showcase the indigenous crops' beauty. The orphan crops were not the focus of the study; instead, it was the permaculture as the focal subject to elaborate on entrepreneurial innovation resulting in the emergence of agri-tourism in the area.

As an entrepreneurial innovation, permaculture necessitates a well-integrated and diverse entrepreneurial ecosystem and resources supported by the locale stakeholders (Assenza, 2016), including the community, local government, and tourists. Management of the physical capital endowments (i.e., orphan crops), sponsorship for the financial capital requirements (i.e., permaculture project), and the rural community's social capital resources needed to be assessed for entrepreneurial innovation to be possible. The community is supposed to collectively contributes to the resource in terms of skills. In that case, entrepreneurial innovation in the form of permaculture can potentially lead to long-term socio-economic growth because entrepreneurial success does not occur in a vacuum but within socio-cultural environments.

According to Fagerberg et al. (2006), innovation cannot be creative in isolation but on extensive interaction with the environment. All entities need to engage in conversation on how to identify and nurture development and growth. Countries, policymakers, and business leaders should consider ways to foster innovation, focusing on general wellbeing. For instance, the ecovillages that focused on the wellbeing of their inhabitants, looking beyond economic growth. The use of time, space, and resources appropriately across sectors needs a wellsupportive environment that promotes collaboration required to foster individuals' sustainable wellbeing in the community. Sustainability intensification requires social infrastructure to enable information flow and incorporate trust among members (Pretty et al., 2011). In this manner, social capital is an essential prerequisite in adopting sustainable behaviors to facilitate collective action and cooperation for the common good.

According to Linkletter and Maciariello (2009), no society can function unless it gives the individual member's social status and function productive. Social institutions make the community cohesive and become willing to contribute to the growth and development, particularly their members' socio-economic wellbeing. In this regard, assessing the social capital resource generation might help realize all of the stakeholder's common goals (i.e., livelihood and welfare).

\section{RESEARCH METHOD}

The study analyzes the community's Willingness to Accept and Willingness to Commit Time in developing permaculture to diffuse entrepreneurial innovation and tourism. Social capital elements, including social networks, trust, and norms, were factors considered to potentially influence the WTA and WTCT. Further, examining the WTA and WTCT in the permaculture project was done to answer the research questions and accomplish the research objectives. This paper adopted a descriptive research design in analyzing and interpreting the data. For the data gathering procedure, a quantitative approach using questionnaires was done to probe the research hypotheses, generate data relevant to the study, and validate the data gathered. A simple frequency distribution table was employed to analyze the respondent's socio-demographic profile, overall mean was used on the respondent's attitude towards WTA, WTCT, and social capital was observed using the arithmetic mean. To enhance the interpretation of the quantitative results, qualitative data was employed. An interview guide was used to generate the respondent's opinions towards the diffusion of entrepreneurial innovation in the community and elicited an in-depth insight into the community's social capital.

This study's locale was at the three barangays of the municipality of Bokod, Province of Benguet, namely Palansa sitio of barangay Bila, Kawal sitio 
of barangay Bobok-Bisal, and barangay Karao due to the existing permaculture project in the area. The participants consisted of members of recognized women organizations and the community's residents.

The socio-demographic profile of the respondents included gender, age, educational background, occupation, income, years of residence, number of household members/family size, land size per family, and affiliation of the respondents to other organizations such as women's group, farmers' group, religious group, neighborhood/village association, political group, school committee, sports group, credit/finance group, and traders/ business group. Data collection contained questions about the Willingness to Accept (WTA) and the Willingness to Commit Time (WTCT) to the permaculture project by the respondents. Also, questions were asked to ascertain the social capital factors contributing to the collectivism needed to strengthen the project.

The respondents were given an informed consent form and official cover letter, asking for their permission to participate in the study. The surveys were administered immediately with paper-and-pencil questionnaires following face-to-face interviews. The participants were assured that any information given in line with the research would be used only for this study, and the survey was conducted professionally using research protocols and research ethics. In gathering the quantitative data, this study employed 20 to 25 minutes of self-administered questionnaires. Respondents were people in the agricultural and non-agricultural sectors, both male and female in the community, who are knowledgeable and experienced about women's organization, farming, and tourism.

The respondents of the study were subjected to a non-probability sampling method. In selecting the sample size, cluster sampling was employed among three barangays of the municipality of Bokod, Province of Benguet. According to the municipality office data, there are 3,843 households within the three barangays, namely,
Bila, Karao, and Bobok-Bisal (see appendix Y). A population sampling depended on the number of respondents willing to answer the survey questionnaires, at an estimated 363 respondents from the population. Using Yamane's formula; $n=\frac{N}{1+N e^{2}}$ Where $\mathrm{n}$ is the sample number, $\mathrm{N}=$ 3,843 is the study area's household population, and $\mathrm{e}=5 \%$ the sampling error.

$$
n=\frac{3,843}{(1+3,843)(0.05)^{2}} \quad n=363
$$

As a result of the effect of the COVID-19 pandemic in the communities and municipal restriction of movement within the barangays, only two hundred and thirteen (213) respondents answered the research questionnaire. In some questions, the study population shows some decline in the number of respondents below 213 because there were questions not answered by some respondents, or the missing data in the cell would have caused it.

The list of women organizations within these three barangays and permission to conduct the study were secured from the Municipal Agriculture Officer. There are seven registered women organizations based on the record from the Municipal Agriculture Office.

\section{Research Conceptual Framework}

The conceptual framework presents Schumpeter's creative destruction as a marker leading to entrepreneurial innovation, which is made evident in the permaculture as a platform to depict the diffusion of entrepreneurial innovation and agritourism. The entrepreneurial innovation hopes to shift the rural area mentality of productbased farming to a more diverse agriculture approach that encompasses tourism. Siemens (2007) believes that this form of tourism can enhance the community's livelihood activities, help revive the rural economy, and improve its infrastructure. Schumpeter's creative destruction emerges the entrepreneurial innovation in the rural community's capacity to develop a new farming pattern that is aesthetically attractive in the context of agritourism. 
Moreover, social capital as the underpinning theory is described in terms of the networks, trust, and norms practiced in the women organizations and community residents relative to their collective management of the permaculture project. This was analyzed in terms of their Willingness to Accept and Willingness to Commit Time to develop the permaculture project. Social capital indicators, including networks, trust, and norms, were used as factors that served to explain the community's Willingness to Accept (WTA) and Willingness to Commit Time (WTCT) in the permaculture project in the community.

The WTA and WTCT analysis is preceded by a mind-setting of the respondents using a survey that follows the Contingent Valuation Method (CVM) (Cao et al., 2012). CVM effectively values non-market nature goods (Cao et al., 2012; Li et al., 2018; Xiong \& Kong, 2017; Wang et al., 2016) and eliciting people's preference on non-market goods. It uses a survey-based methodology with an appropriately designed questionnaire in order to describe a hypothetical market. In the study, the non-market good is permaculture to diffuse entrepreneurial innovation and agritourism. According to Pearce et.al. (2002), contingent valuation questions begin by outlining a scenario providing a clear description of the non-market good. Consequently, the respondents are presented with a project that will be undertaken and which they have to evaluate in terms of the benefit they will receive. The project description also includes the valuation questions about their expected engagement in the project. Since the permaculture project is a future project, using the contingent valuation method can help predict the entrepreneurial innovation diffusion.

\section{RESULT AND DISCUSSION}

Table 1 shows gender, occupation, employment, years of education, number of households, and years of residence. Age and Average household monthly income data respectively. These independent variables were deemed relevant variables in the study.

\section{Knowledge and Awareness of Orphan Crops in the Community}

Table 2. Respondent's Knowledge and Awareness of Orphan crops in the Community

\begin{tabular}{lcc}
\hline & Frequency & Percentage \\
\hline I know all of them & 39 & 18.31 \\
\hline I know some of them & 159 & 74.65 \\
\hline I don't know them & 15 & 7.04 \\
\hline
\end{tabular}

Source: Umeh, et al, 2021

When asked if they were familiar with any of the orphan crops listed in the questionnaire, the respondents said yes. $74.65 \%$ of those surveyed said they were familiar with some of the orphan crops. This demonstrates that the farmers are aware of the community's orphan crops. It will not be difficult to introduce the notion of using permaculture to manage orphan crops in the community. That $18.31 \%$ knew what there was to know about everything to plant and manage the orphan crops in a permaculture homestead.

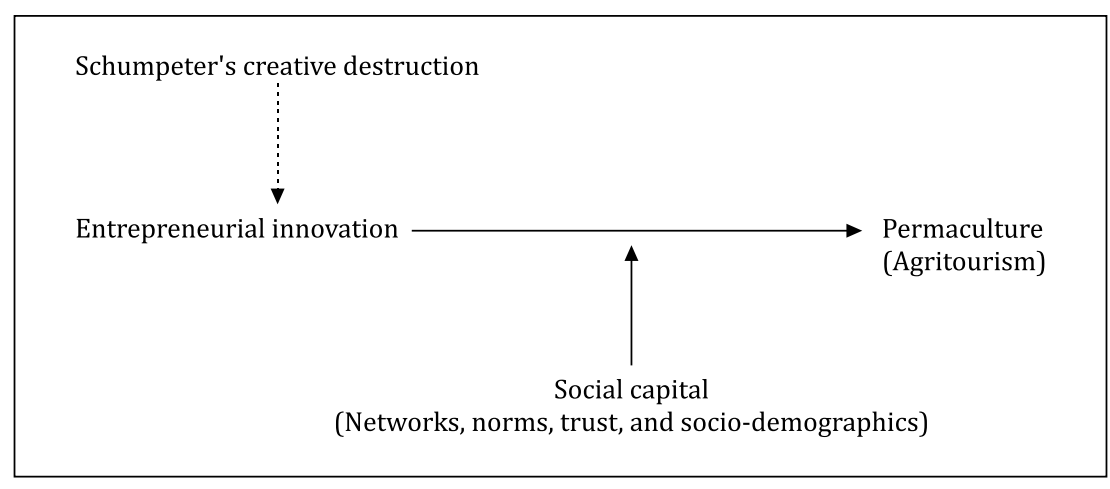

Source: Umeh, et al, 2021

Figure 1. Conceptual Framework 
Table 1. Distribution of the Respondents According to Some Demographic Variables

\begin{tabular}{|c|c|c|}
\hline Demographic Profile & Frequency & Percentage \\
\hline \multicolumn{3}{|l|}{ a. Gender } \\
\hline Male & 87 & 40.8 \\
\hline Female & 126 & 59.2 \\
\hline Total & 213 & 100 \\
\hline \multicolumn{3}{|l|}{ b. Occupation } \\
\hline Student & 11 & 5.2 \\
\hline Farmer & 118 & 55.4 \\
\hline Hired labor & 19 & 8.9 \\
\hline Off-farm business & 8 & 3.8 \\
\hline Owner/farm business & 7 & 3.3 \\
\hline Employed & 50 & 23.5 \\
\hline Total & 213 & 100 \\
\hline \multicolumn{3}{|l|}{ c. Employment } \\
\hline Agricultural & 136 & 63.8 \\
\hline Non-agricultural & 55 & 25.8 \\
\hline Others & 20 & 9.4 \\
\hline Missing & 2 & .9 \\
\hline Total & 213 & 100 \\
\hline \multicolumn{3}{|l|}{ d. Years of Education } \\
\hline Elementary & 24 & 11.27 \\
\hline High school & 75 & 35.21 \\
\hline College & 108 & 50.70 \\
\hline Postgraduate degree & 6 & 2.82 \\
\hline Total & 213 & 100 \\
\hline \multicolumn{3}{|c|}{ e. Number of household members/ family size } \\
\hline $1-2$ & 28 & 13.15 \\
\hline $3-4$ & 88 & 41.31 \\
\hline $5-6$ & 68 & 31.92 \\
\hline more than 6 & 29 & 13.62 \\
\hline Total & 213 & 100 \\
\hline \multicolumn{3}{|l|}{ f. Years of residence } \\
\hline less than 5 years & 10 & 4.69 \\
\hline $5-10$ years & 24 & 11.27 \\
\hline 11- 15 years & 34 & 15.96 \\
\hline more than 15 years & 140 & 65.73 \\
\hline not applicable & 5 & 2.35 \\
\hline Total & 213 & 100 \\
\hline
\end{tabular}

Source: Umeh, et al, 2021

Seven point four percent (7.04\%) of the respondents indicated that they didn't know the orphan crops. This means that workshops were needed to be organized to create more awareness about orphan crops and their importance to humans and the community.
In addition, the respondents also perceived that the local government could develop policies that support orphan crop planting to enhance the community's agri-tourism. The study results affirm that orphan crops are underutilized crops (Maddison-Harris \& FTA, 2018) and have 
potential if they are fully explored. According to Tadele (2019), Caselli-Mechael (2015), these crops are wildly growing and thriving abundantly in the area. These crops are resilient and adaptive to environmental stress and provide an indispensable source of staple food to the vast majority of less privileged farming communities (Assefa, 2014).

\section{Willingness to Accept the Permaculture}

Among the indicators, the respondents' Willingness to Accept permaculture was determined with this question, "Do you think the permaculture landscapes can offer benefits to the community?". This was to ascertain the entrepreneurial innovation's (permaculture) acceptability in the community. Table 3 above shows that $79.80 \%$ of the respondents indicated Willingness to Accept the permaculture. This is supported by the $83.60 \%$ of respondents who perceived that orphan crops needed to be preserved, and $80.80 \%$ of respondents affirmed that they wish to sustain these orphan crops for the next generations to come. Thus, the findings suggest that the respondents were aware of the values and benefits that permaculture brings to the community. This is evident in the $3.80 \%$ who answered NO to the question, "do you think the permaculture will help in the community's agritourism development?" vis-à-vis the $71.40 \%$ who answered YES to the same question. The data gathered shows that the community was willing to accept the permaculture, leading to the diffusion of entrepreneurial innovation and tourism. It implies that permaculture is a promising approach when situated in a rural community. Didarali and Gambiza (2019) added that permaculture enhances farmers' ability to handle environmental problems and supports livelihood activities. It can drive local economic growth, improve rural communities' wellbeing, and act as a leisure source that contributes to local economies through tourism. According to Vidickienè et al. (2020) stated that tourism plays a vital role in attracting economic and social development to a rural area suffering from depopulation due to economic decline.

\section{Willingness to Commit Time in the Development of the Permaculture}

When the respondents were asked as to their Willingness to Commit Time in the permaculture project, out of $213,84.50 \%$ or 180 answered YES, and $15.50 \%$ or 33 answered NO. The majority of respondents (84.50\%) indicated their Willingness to Commit Time to the project. This showed their enthusiasm for managing and developing the permaculture project in

Table 3. Respondents' Willingness to Accept the Permaculture

\begin{tabular}{|c|c|c|c|c|c|c|}
\hline & \multicolumn{2}{|c|}{ YES } & \multicolumn{2}{|c|}{ NO } & \multicolumn{2}{|c|}{ Not sure } \\
\hline & $\boldsymbol{F}$ & $\%$ & $f$ & $\%$ & $\boldsymbol{F}$ & $\%$ \\
\hline 1. Do you think these orphan crops need to be preserved by the community? & 178 & 83.6 & 12 & 5.6 & 23 & 10.8 \\
\hline 2. Do you wish to sustain these orphan crops for the next generations to come? & 172 & 80.8 & 12 & 5.6 & 29 & 13.6 \\
\hline 3. Do you think the permaculture can offer benefits to the community? & 170 & 79.8 & 10 & 4.7 & 33 & 15.5 \\
\hline 4. Do you think the permaculture will be harmful to the community? & 47 & 22.1 & 105 & 49.3 & 61 & 28.6 \\
\hline 5. Do you wish tourists to see these orphan crops planted in the permaculture? & 154 & 72.3 & 12 & 5.6 & 47 & 22.1 \\
\hline $\begin{array}{l}\text { 6. Do you think tourists will be attracted to visit the community if these orphan crops } \\
\text { are planted in the permaculture? }\end{array}$ & 148 & 69.5 & 9 & 4.2 & 56 & 26.3 \\
\hline $\begin{array}{l}\text { 7. Do you think the permaculture will help in the community's agri-tourism } \\
\text { development? }\end{array}$ & 152 & 71.4 & 8 & 3.8 & 53 & 24.9 \\
\hline
\end{tabular}

Source: Umeh, et al, 2021

Table 4. Respondents' Willingness to Commit Time in the Development of the Permaculture

\begin{tabular}{lccc}
\hline & \multicolumn{2}{c}{ Frequency } & \multicolumn{2}{c}{ Percentage (\%) } \\
\hline Are you willing to volunteer some of your time to help with the $\mathbf{p}$ & YES & 180 & 84.5 \\
\cline { 2 - 3 } ermaculture project to develop agri-tourism in your community? & NO & 33 & 15.5 \\
\hline
\end{tabular}

Source: Umeh, et al, 2021 
Their community. This study shows that the respondents expressed their desire to commit time to develop the permaculture because they know its benefits. This finding is corroborated by Faleyimu's (2014) study that most respondents are willing to participate and commit time to develop and manage projects of plant trees to live in a green environment. Likewise, Ajewole (2015) revealed that residents are willing to be physically involved and commit time to contribute to the development of entrepreneurial innovation situated in their community, which would bring development and improve the residents' wellbeing (Ajewole, 2002). Permaculture encourages neighborhood networks and people participation to motivate the change. It will help expand resources, labor, knowledge (Jonathon, 2017) and setting up a beneficial network to connect people with likeminded pursuits.

\section{Willingness to Commit Time in the Permaculture}

Out of the 180 respondents who answered yes, 78 answered that the community should be willing to participate in the permaculture project. Social capital provides a wide range of positive outputs to the residents to participate and help the community come together voluntarily and contribute to taking care of their territories and the resources that sustain their livelihood. This implies that community members' participation should be encouraged. Community participation leads to activities that would support permaculture diffusion as an entrepreneurial innovation resulting in agritourism development. It would encourage entrepreneurial activity among participants to innovate and create local solutions to develop and manage the permaculture for agritourism. This coincides with Halder et al.'s (2014) study that it is necessary to have the community participate in the permaculture garden. This affirms McCarthy and Schurmann's (2015) study, which revealed that farmers shifting to an innovative farming method for sustainability lack institutional support as one of their factors. The respondent's perception can explain that permaculture is idealistic and challenging to implement (Vitari \& David, 2017) in the community by the local government.

\section{Willingness to Commit Time in Permaculture in terms of the Amount of Time to Render}

Table 6. Respondents' Willingness to Commit Time in Permaculture in terms of the Amount of Time to Render

\begin{tabular}{lcc}
\hline $\begin{array}{l}\text { How much time are you w } \\
\text { illing to commit to taking } \\
\text { care of the permaculture } \\
\text { project daily? }\end{array}$ & Frequency & Percentage \\
\hline 1 hour in a day & 72 & 33.8 \\
\hline 2 hours in a day & 76 & 35.7 \\
\hline 3 hours in a day & 17 & 8.0 \\
\hline 4 hours in a day & 10 & 4.7 \\
\hline More than 4 hours in a day & 5 & 2.3 \\
\hline
\end{tabular}

Source: Umeh, et al, 2021

The respondent's Willingness to Commit Time to permaculture project was measured in terms of the amount of time to be rendered in hours per day. If the permaculture project were pursued, they would spend one to two (1-2) hours a day developing and managing entrepreneurial innovation. The permaculture concept requires people to be physically involved in developing and managing its landscape. Their involvement can encourage local solutions to a shared goal of nurturing the environment. This implies that the community's Willingness to Commit Time

Table 5. Respondent's reasons on Willingness to Commit Time in the Permaculture

\begin{tabular}{|c|c|c|}
\hline & Frequency & Percentage \\
\hline a. Creating a permaculture planted with orphan crops is not much of a problem & 41 & 19.20 \\
\hline b. The community should be willing to participate in the permaculture project & 78 & 36.60 \\
\hline c. I am not confident that my contribution will be used with due diligence by the local government & 14 & 6.60 \\
\hline d. I believe that my active participation will lead to the development of agritourism in the community & 44 & 20.70 \\
\hline e. I don't understand the proposed project & 3 & 1.40 \\
\hline
\end{tabular}

Source: Umeh, et al, 2021 
goes with volunteering 1- 2 hours daily for the project's success. The project's benefits on the community trigger the respondent's enthusiasm to commit 1-2 hours daily to develop the permaculture in their community. Compared to Ajewole (2015) study, 13.9\% were willing to commit 2 hours per week to the Urban Forestry Development. Those willing to commit time were aware of the project's benefits to the community.

Relationship Between the Willingness to Accept in Terms of Socio-demographics and Social Capital Factors

Table 7 also shows a significant relationship at the 0.05 level. This is based on the omnibus test result where the chi-square statistic has an associated p-value of 0.033 . The predictors "years of education" and "norms" were the significant independent variables. Years of education with a p-value of 0.011 shows a significant correlation with respondent WTA at the 0.05 significance level, indicating a positive relationship between WTA and education. The probability of accepting the permaculture will increase by 0.362 with a unit increase in education years. This means that there's a probability of 0.59 that the person is Willing to Accept if the number of years in school is high.

This finding implies that farmers with more educational attainment like training and workshop are more environmentally conscious and are willing to accept the permaculture project. Farmers with higher education levels are well informed and knowledgeable to ascertain the benefits the diffusion of entrepreneurial innovation would bring to the community.

This finding is in consonance with the study of Ajewole (2015) that the higher an individual gets in education level, the more environmentally conscious the individual becomes. According to Xiong and Kong (2017), farmers with higher education understand the importance of environmental protection and wetland ecology improvement. Likewise, Nyongesa (2016) found out that farmers with higher education levels understand the Payment for Environmental Services (PES) scheme better and make a knowledgeable decision when evaluating ecosystems.

Relationship between the Willingness to Commit Time in Terms of the Sociodemographic and Social Capital Factors.

In the study, the following predictor variables $\mathrm{X} 1$ age, X2 years of education, X3 income, X4 family size, $X 5$ number of hours, $X 6$ social network, $X 7$ trust, and $X 8$ norms in testing the relationship between the respondents' Willingness to Commit Time and socio-demographics with the binary logistic regression were considered. It means that there was a very high probability of 0.83 that the person was Willing to Commit Time in the permaculture if the rating on social networks was high. The respondents understood the potential and benefits of entrepreneurial

Table 7. Summary of the Results of the Binary Logistic Regression Testing the Relationship Between the Respondents "Willingness to Accept" and Some Perceived Factors

\begin{tabular}{|c|c|c|c|c|c|c|}
\hline Predictor & B & S.E. & Wald & $\mathbf{f}$ & p-value & $\operatorname{Exp}(B)$ \\
\hline Age & -0.015 & 0.036 & 0.170 & & 0.680 & 0.985 \\
\hline Years of education & 0.362 & 0.143 & 6.440 & & $0.011^{*}$ & 1.436 \\
\hline Income & 0.000 & 0.000 & 2.980 & & 0.084 & 1.000 \\
\hline Family size & -0.375 & 0.394 & .905 & & 0.341 & 0.687 \\
\hline Social networks & 2.370 & 1.307 & 3.286 & & 0.070 & 10.693 \\
\hline Trust & -0.932 & 1.376 & .459 & & 0.498 & 0.394 \\
\hline Norms & -2.606 & 1.260 & 4.276 & & $0.039^{*}$ & 0.074 \\
\hline Constant & 4.677 & 3.515 & 1.771 & & 0.183 & 107.462 \\
\hline
\end{tabular}

Source: Umeh, et al, 2021 
Table 8. Summary of the Results of the Binary Logistic Regression Testing the Relationship Between the Respondents "Willingness to Commit Time" and Some Perceived Factors

\begin{tabular}{|c|c|c|c|c|c|c|}
\hline Predictor & B & S.E. & Wald & f & p-value & $\operatorname{Exp}(B)$ \\
\hline Age & 0.025 & 0.022 & 1.253 & & 0.263 & 1.025 \\
\hline Years of education & 0.052 & 0.083 & 0.392 & & 0.531 & 1.053 \\
\hline Income & 0.000 & 0.000 & 0.194 & & 0.66 & 1.000 \\
\hline Family size & -0.117 & 0.265 & 0.193 & & 0.66 & 0.890 \\
\hline Number of hours & & & 3.833 & & 0.574 & \\
\hline Number of hours (1) & -20.744 & 16004.338 & 0.000 & & 0.999 & 0.000 \\
\hline Number of hours (2) & -20.235 & 16004.338 & 0.000 & & 0.999 & 0.000 \\
\hline Number of hours (3) & -21.290 & 16004.338 & 0.000 & & 0.999 & 0.000 \\
\hline Number of hours (4) & -20.635 & 16004.338 & 0.000 & & 0.999 & 0.000 \\
\hline Number of hours (5) & -21.225 & 16004.338 & 0.000 & & 0.999 & 0.000 \\
\hline Social networks & 1.591 & 0.727 & 4.795 & & $0.029 *$ & 4.908 \\
\hline Trust & 0.240 & 0.701 & 0.117 & & 0.732 & 1.272 \\
\hline Norms & -0.420 & 0.670 & 0.393 & & 0.531 & 0.657 \\
\hline Constant & 16.900 & 16004.338 & 0.000 & & 0.999 & 21861666.77 \\
\hline
\end{tabular}

Source: Umeh, et al, 2021

innovation (permaculture) through their social networks, heightening their WTCT in the permaculture project. This study shows that social networks influence attitude towards WTCT to permaculture project, which leads to the adoption of new behavior in the community. This study's result is affirmed by the study of Kohler et al.(2007), stating that interaction within one's social network affects the individual's consideration of new behaviors. Monge (2008) also stated that social interaction supports the adoption of innovation among farmers. It forms a strong synergy for people to act collectively and commit time to develop and manage the permaculture project.

\section{Permaculture relationship with agritourism}

The respondents indicated that "support agricultural livelihood activities" as the highest contribution of permaculture to agritourism in the community because they were in dire need of another source of livelihood. The community inhabitants depend mostly on farming and agricultural produce for livelihood, which made their population migrate to the urban settlement for job opportunities. This finding implies that agritourism increases the source of income for a farm-based livelihood. Agritourism provides new opportunities for work, education, and how the agricultural industry should be. The respondents believed that the permaculture

Table 9. Permaculture Relationship with Agritourism

\begin{tabular}{lcc}
\hline How the permaculture project can contribute to agri-tourism in the community & Mean & Rank \\
\hline Support agricultural livelihood activities & 2.20 & 1 \\
\hline Reduce environmental degradation & 2.24 & 2 \\
\hline Showcase indigenous (orphan) crops abundant in the community & 2.28 & 3 \\
\hline Attract guests and tourists to the community & 2.38 & 4 \\
\hline Improve the landscape of the community (e.g., artistic scenery) & 2.41 & 5 \\
\hline Create a place for socialization (e.g., a meeting of cultures) & 2.46 & 6 \\
\hline Support local government policies & 2.49 & 7 \\
\hline Overall Mean & 2.35 & \\
\hline
\end{tabular}

Source: Umeh, et al, 2021 
project would set the pace for agritourism development in the community, knowing that tourism is one tool for rural area development. This result of the study is supported by Siemens's (2007) study that tourism can enhance the community's livelihood activities, help revive the rural economy, and improve its infrastructure. The results are interpreted to mean that the community hopes to support local government policies such as creating a place for socialization, improving the community's landscape, and attracting tourists through permaculture to enhance agritourism. This is evident in the overall mean (2.35) of the result, which is supported by the study of Howe and Wheeler (1999) that permaculture acts as a source of leisure that contributes to local economies through tourism.

\section{CONCLUSION AND RECOMMENDATION}

\section{Conclusion}

This paper analyzed the Willingness to Accept and Willingness to Commit Time in the permaculture project to facilitate entrepreneurial innovation and tourism diffusion. The permaculture project is considered an entrepreneurial innovation that characterizes a shift from the old farming approach to a new farming approach that can enhance agritourism's propensity in the rural community. The permaculture is an ongoing project in the study's locale, which is hoped to be shared in other communities. Hence, the diffusion of entrepreneurial innovation was emphasized in the discussions. Consequently, the development of agritourism is expected to emerge. In the study, tourism was noted as the missing market that is to be achieved as a spillover of the entrepreneurial innovation.

Permaculture project is considered an entrepreneurial innovation that characterizes a shift from the old farming approach to a new farming approach. The permaculture is an ongoing project in the study's locale, which is hoped to be shared in other communities. Community residents and representatives of the women organizations who participated in the research are willing to volunteer 1-2 hours daily for the project's development. In the years of education and norms were considered to have a significant relationship. Social networks influence the WTCT, which can serve as a basis for strengthening entrepreneurial innovation diffusion. Regarding the predictors for Willingness to Accept, the years of education and norms were considered to have a significant relationship. Education in terms of training and workshop can increase environmental consciousness awareness and improve the WTA and WTCT to the permaculture project.

As regards the predictors for Willingness to Commit Time, the social network showed a significant relationship. This means that social networks influence the WTCT, which can serve as a basis for strengthening entrepreneurial innovation diffusion. Policymakers promote the community's cohesive relationship to hasten the permaculture project's implementation and fast-track stakeholder benefits by engaged all stakeholders in the entire process of diffusing entrepreneurial innovation in communities to avert the doubt within the community. Reinforcing norms associated with excessive punishments and sanctions can decrease an individual's WTA environmental goods like permaculture. Permaculture projects necessitate nurturing harmonious social networks. The community people disagree to accept the permaculture project if the community would be expected to be punished for not contributing time and effort to the permaculture. There were restrictions of movement due to the Covid-19 pandemic, which hampered the data-gathering processes. There is no literature on permaculture in Bokod, even though some permaculture landscape and practices exist in the community. The study was restricted to the diffusion of entrepreneurial innovation within the community. This study focused more on the benefits of permaculture in the community without discussing its disadvantages to the respondents. The researchers recommends that further studies should consider the disadvantages of permaculture in the community regarding cultivation and management. 


\section{Recommendation}

This study contributes the following ideas to help resolve issues in diffusing entrepreneurial innovation and tourism in the community. Practitioners and policymakers should engage all stakeholders in the entire process of diffusing entrepreneurial innovation in communities to avert the doubt within the community. It was evident in the paper that cooperation among stakeholders leads to collective action that restrains opportunistic acts and accepts the permaculture project for agritourism.

In this study, it was apparent that when the question "Do you think the permaculture will be harmful to the community?" was asked, $28.6 \%$ of the respondents answered that they were not sure. When diffusing Entrepreneurial innovation in an area, the community members should be sensitized/educated on the project, both on its benefits and disadvantages. From the study, we observe that when respondents answered the contingency valuation question, they considered more of the project's benefits.

Furthermore, the communities should promote activities that will connect farmers, even using different social networks to connect to their organizations in other areas, by encouraging their people to interact, exchange, and collaborate. These activities can occur through farmers' workshops, training, and entrepreneur activities in the community. need to be improved in communities among residents and organization members to achieve a well-functioning society. Social networks are crucial factors for behavioral change and diffusion of innovation. Innovation promoters should encourage social interaction among individuals to attract resources and WTCT to the entrepreneurial innovation in the community. Innovation is an interactive process; the respondents accepted the entrepreneurial innovation (Permaculture) because they deciphered its benefits through social networks.

In diffusing non-market goods like permaculture for agritourism that requires the community's voluntary participation, it was evident in this paper that punishment and sanction did not yield the willingness to accept in this empirical paper founds. The concept of using punishment to shape behavior should be reconsidered in terms of diffusing entrepreneurial innovation (permaculture) in a community.

The findings of the study can help the local government coordinate with the women's organizations to develop favorable policies that encourage the community to adopt permaculture as a new approach in sustainable farming practices. The local government has to reach out to the community to understand their needs, address their challenges, increase the community and farmer's confidence towards government projects like permaculture, and increase institutional support for non-market or intangible resource goods. The government (National, Regional, State, and local) and its agents should make adequate policies that reflect society. Such policies will bring the people closer to the government and boost public trust in the government. Government should also have a blueprint that helps farmers provide training, workshops, and financial support to local farmers venturing into sustainable agriculture like permaculture.

Rural agrarian communities should have strategies to develop their cultural heritage, create a place for socialization, and improve the community's landscape for tourism to attract visitors. These activities will increase the community as tourist destination, which will serve as sources of livelihood for the community. 


\section{REFERENCES}

Ajewole, 0. I. (2002). Prospect for participatory urban forestry development in Ibadan Metropolis. Journal of Tropical Forest Resources, Vol. 18, No 1, pp. 86-100.

Ajewole, O. I. (2015). Public willingness to commit time to urban forestry development in Lagos Metropolis,Nigeria. Journal of Agriculture and Social Research (JASR,15(1).

Akhtar, F., Suleman, A., \& Safdarshah, K. (2014). Permaculture: An ethical and valued based system for sustainable Management. Journal of Business Strategies, 8(2), 113-126

Akhtar, F., Lodhi, S. A., \& Khan S. S. (2015). Permaculture approach: Linking ecological sustainability to businesses strategies. Management of Environmental Quality: An International Journal, 26(6), 795-809. https://doi.org/10.1108/MEQ-01-2015-0001

Assefa, K. (2014). The dire need to support 'orphan crop' research. Appropriate Technology, Vol.41, No 2. www.appropriate-technology.com

Assenza, P. (2016). Identifying fertile ground: Peripheral stakeholder contribution to a healthy entrepreneurial ecosystem. Journal of Business and Entrepreneurship, 28 (1), 31.

Barbieri, C., \& Mshenga, P. M. (2008). The Role of the firm and owner characteristics on the performance of agritourism farms. Sociologia Ruralis, 48(2),166-183. https://doi.org/10.1111/j.14679523.2008.00450.x.

Birnbaum, J., \& Fox, L. (2014). Sustainable revolution: Permaculture in ecovillages, urban farms, and communities worldwide. Berkeley, pp. 368.

Bostaph, S. (2013). Driving the market process:"Alertness" versus innovation and "Creative Destruction", The Quarterly Journal of Austrian Economics, Vol.16,No 4, pp. 1-7.

Cao, J., Holden, N., Yanyan, Q., \& Song, X. (2012). Potential use of Willingness to Accept (WTA) to compensate herders in Maqu County, China for reduced stocking. Rangeland Ecology \& Management, Vol. 65, No 4, pp. 533-537. https://doi.org/10.2307/41681574.

Carden, A. (2011). Economic progress and entrepreneurial innovation: Case studied from Memphis. Southern Journal of Entrepreneurship Vol. 4,No 1, pp. 36-48.

Caselli-Mechael, L. (2015, Nove mber 4)."Orphan Crops": What they are, why they matter, and what's being done. Food Insight. https://foodinsight.org/orphan-crops-what-they-are-why-they-matter-andwhats-being-done/

Catholic Relief Services (2008). Homestead gardening: A manual for program managers, implementers, and practitioners. https://www.crs.org/sites/default/files/tools-research/homestead-gardening.pdf.

Chiang, L. L., Kim, J., Tang, L. R., \& Bosselman, R. (2017). Exploring agritoursim entrepreneurship strategies: Antecedents and consequences. Journal of Marketing Management, Vol. 5, No 1, pp. 56-69.

Chiromo, P. \& Kazembe, C. (2016). Social innovation and agro-tourism growth in rural communities of Zimbabwe; https://www.academia.edu/34174984/SOCIAL_INNOVATION_AND_AGROTOURISM_GROWTH_IN_RURAL_COMMUNITIES_OF_ZIMBABWE

Chua-Barcelo, R. T. (2014). Ethno-botanical survey of edible wild fruits in Benguet, Cordillera administrative region, the Philippines. Asian Pacific Journal of Tropical Biomedicine, Vol. 4, No 1, pp.525-538. https://doi.org/10.12980/apjtb.4.201414b3.

Didarali, Z., \& Gambiza, J. (2019). Permaculture: Challenges and benefits in improving rural livelihoods in South Africa and Zimbabwe; Sustainability, file:///C:/Users/dell/Downloads/sustainability11-02219-v2.pdf

Drăgoi, M., Iamandi, I.-E., Munteanu, S., Ciobanu, R., Țarțavulea (Dieaconescu), R., \& Lădaru, R. (2017). Incentives for developing resilient agritourism entrepreneurship in rural communities in Romania in a European context. Sustainability, Vol. 9, No 12, pp. 2205. https://doi.org/10.3390/ su9122205. 
Umeh Azubuike Lucky, Leilani I. De Guzman / Diffusing Entrepreneurial Innovation And Tourism: An Empirical Evidence of Permaculture / 118 - 137

Eurac Research (2018). 1st world congress on agritourism. Bozen/Bolzano, 7-9.

Fagerberg, J., Mowery, D., \& Fagerberg, J. (2006). Innovation: A guide to the literature in the Oxford handbook of innovation. Oxford University Press. https://www.oxfordhandbooks.com/view/ 10.1093/oxfordhb/9780199286805.001.0001/oxfordhb 9780199286805-e-1.

Faleyimu, O., I. (2014). Public perceptions of urban forests in Okitipupa, Nigeria: Implication for environmental conservation. JASEM, Vol. 18, No 3, pp. 469-478.

Gruère, G. P., Giuliani, A., \& Smale, M. (2006). Marketing underutilized plant species for the benefit of the poor: A conceptual framework. SSRN Electronic Journal. https://doi.org/10.2139/ssrn.916572

Halder, S., Martens, D., Hehl, F., \& Zacharias, M. (2014). Sustainable community gardening incities.https:// www.researchgate.net/publication/280311030_Sustainable_Community_Gardening_in_Cities.

Hjalager, A. (2014). Disruptive and sustaining innovations: The case of rural tourism. https://doi.org/ $10.4337 / 9781782548416.00009$.

Holmgren, D. (2002). Permaculture: Principles \& pathways beyond sustainability. Hepburn, Vic.: Holmgren Design Services.

Holstein, S. V. (2013). A permaculture take on eco-tourism. Permaculture magazine https:// www.permaculture.co.uk/articles/permaculture-take-eco-tourism.

Howe, J., \& Wheeler, P. (1999). Urban food growing: The experience of two UK cities. , Vol. 7, 1, pp. 13-24. doi:10.1002/(sici)1099-1719(199902)7:1<13::aid-sd100>3.0.co;2-b.

Jegdic, V., Skrbic, I., \& Milosevic, S. (2017). Models of entrepreneurship development in rural tourism destinations in Vojvodina. Ekonomika poljoprivrede. Vol. 64,No 4,pp. 221-237. https://doi.org/ 10.5937/ekoPolj1701221J.

Jonathon, E. (2017, April 21). Using the community as part of your own permaculture design. https:// www.permaculturenews.org/2017/04/21/using-community-part-permaculture-design/

Kokkranikal, J., \& Morrison, A. (2011). Community networks and sustainable livelihoods in tourism: The role of entrepreneurial innovation. Tourism Planning \& Development, Vol. 8, No 2, pp. 137156. https://doi.org/10.1080/21568316.2011.573914

Kohler, H., P., Behrman, J., R., \& Watkins, S., C. (2007). Social networks and HIV/AIDS risk perceptions. Demography, Vol.44, No 1, pp. 1-33. doi:10.1353/dem.2007.0006.

Li, B., \& Huang, L. (2019). The Effect of incremental innovation and disruptive innovation on the sustainabledevelopment of manufacturing in China. SAGE Open. 9. https://doi.org/ $10.1177 / 2158244019832700$.

Li, H., Yang, X., Zhang, X., Liu, Y., \& Zhang, K. (2018). Estimation of rural households' Willingness to Accept two PES programs and their service valuation in the Miyun reservoir catchment, China. Sustainability, Vol. 10, No 2, pp. 170. https://doi.org/10.3390/su10010170

Linkletter, K. E \& Maciariello, J. A. (2009). Genealogy of a social ecologist; Journal of Management History, 15(4),pp. 334-356. https://doi.org/10.1108/17511340910987284

Maddison-Harris, H., \& FTA Forests, Trees and Agroforestry (2018). Orphan crops for improving diets. Forest, Tree and Agroforestry. https://www.foreststreesagroforestry.org/news-article/orphancrops-for-improvingdiets/

Madeley, J (2002). Food for all: the need for a new agriculture. Appropriate Technology, 29, (2).: Business Premium Collection pg 32.

Malik, A. A., \& Chaudhary, G. (2018). Global food security: A truncated yield of underutilized and orphan crops. Biotechnology Products in Everyday Life, 161-171. https://doi.org/10.1007/978-3-31992399-4_11

McCarthy, B., \& Schurmann, A. (2015). Sustainable horticulture in North Queensland: Resistance to the adoption of innovations? Journal of New Business Ideas \& Trends, Vol.13, No 2, pp. 15 - 38.

McDaniel, B. A. (2010) "The Social and Institutional Economics of the Original Schumpeter"; Association for Social Economics. https://doi.org/10.1007/s12143-009-9049-6 
Monge, M., Hartwich, F., \& Halgin, D. (2008). How change agents and social capital influence the adoption of innovations among small farmers: Evidence from social networks in rural Bolivia. Washington, DC: International Food Policy Research Institute, pp.1-68.

Morel, K., Léger, F., \& Ferguson, R. S. (2018). Permaculture. Reference Module in Earth Systems and Environmental Sciences.

Mwendwa, M. (2019). Case Study: Finding a way out of the maize Agroecology: The Bold Future of Farming in Africa. pp. 70 - 73

Nyongesa, J. M., Bett, H. K., Lagat, J. K., \& Ayuya, O. I. (2016). Estimating farmers' stated willingness to accept pay for ecosystem services: case of Lake Naivasha watershed Payment for Ecosystem Services scheme-Kenya. Ecological Processes, Vol. 5, No 1, pp. 13 -24. https://doi.org/10.1186/s13717-0160059-z.

Ollenburg, C., \& Buckley, R. (2007). Stated economic and social motivations of farm tourism operators. Journal of Travel Research, 45(4), 444-452. https://doi.org/10.1177/0047287507299574.

Pearce, D., Pearce, C., \& Palmer, C., (2002). Valuing the environment in developing countries. Case studies. Edward Elgar Publishing Limited.

Pérez, R. M. (2015). "Cultural and communication industries: Myth and logic of the terms creativity and entrepreneurial innovation". Revista Latina de Comunicación Social, Vol. 70, pp. 813 - 832. https:/ /doi.org/10.4185/RLCS-2015-1073en.

Permatil (2006). Resource book for permaculture: Solutions for sustainable lifestyles. http://library.uniteddiversity.coop/Permaculture/Permaculture_Reference_Book.pdf

Pretty, J., Toulmin, C., \& Williams, S. (2011). Sustainable intensification in African agriculture. International Journal of Agricultural Sustainability 9(1) pp. 5-24, https://doi.org/10.3763/ijas.2010.0583.

Ramírez L. J. C., Sánchez-Cañizares, S. M., \& Fuentes-García, F., J. (2019). Past themes and tracking research trends in entrepreneurship: A co-word, cites and usage count analysis. sustainability Article.

Schilling, B., J., \& Sullivan, K., P. (2014). Characteristics of New Jersey agritourism farms. Journal of Food Distribution Research, 45(2).

Schmidt, K. (2016). Book review; sustainable [R]evolution: Permaculture in ecovillages, urban farms, and communities worldwide. By Juliana Birnbaum and Louis Fox. Berkeley, CA: North Atlantic Books, 2014, 368 pp. ISBN: 9781583946480 . Canadian Journal of Nonprofit and Social Economy Research Revue canadienne de recherche sur les OBSL et l'économie sociale ANSERJ, 7(2), pp. 82 - 84 https:// anserj.ca/index.php/cjnser/issue/download/13/1

Schumpeter, J.A. (1939).Business cycles: A theoretical, historical and statistical analy-sis of the capitalist process, New York: McGraw-Hill.

Siemens, L. (2007). Challenges faced by rural/remote tourism businesses on Vancouver Island: an exploratory study. Journal of Enterprising Communities: People and Places in the Global Economy, Vol. 1, No 4, pp. 308- 320. https://doi.org/10.1108/17506200710833818.

Silvestrelli, P. (2012). Entrepreneurial innovation for cultural tourism development: Impresa ProgettoElectronic Journal of Management, $n(2)$

Sledzik, K. (2013). Schumpeter's view on innovation and entrepreneurship. SSRN Electronic Journal. Doi: $10.2139 /$ ssrn.2257783.

Stanovčić, T., Peković, S., Vukčević, J., \& Perović, D. (2018). Going entrepreneurial: Agro-tourism and rural development in Northern Montenegro. Business Systems Research Journal, Vol. 9,No 1, pp. 107117. https://doi.org/10.2478/bsrj-2018-0009

Stehen, S., M. (2013). The official rhetoric of permaculture motivating behaviour change through environmental communication. Australian Journal of Communication. 36(2)

Stolarick, K., Denstedt, M., Donald, B., \& Spencer, G. M. (2010). Creativity, tourism and economic development in a rural context: The case of Prince Edward County. Journal of Rural and Community Development,Vol. 5,No 12, pp. 238-254. 
Surugiu, C. (2009). Development of rural tourism through entrepreneurship. Revista de turism Journal of tourism. Vol. 8, No 10,pp 64-75

Swart, I. \& Orsmond, E. (2010). Positioning a research agenda on the social economy: The new capitalist expansion and its impact on worker conditions in a changing South African agricultural setting; International Journal of Social Economics, Vol. 37,No 12, pp. 900-922. https://doi.org/ 10.1108/03068291011082991

Tadele, Z. (2019). Orphan crops: Their importance and the urgency of improvement. Planta Vol. 5, No. 250, pp. 677-694. https://doi.org/10.1007/s00425-019-03210-6

Vella, S. S. (2010). Sustainable agricultural management and landscaping through agroforestry and permaculture case study: Northern Malta; JMU Scholarly Commons, Masters Theses. 433. https:// commons.lib.jmu.edu/master201019/433.

Vidickienė, D., Vilkė, R., \& Gedminaitė-Raudonė, Z. (2020).Transformative tourism as an innovative tool for rural development. Europ. Countrys. Vol. 12, No 3, pp. 277-291.

Vitari, C. \& David, C. (2017). Sustainable management models: innovating through Permaculture. Journal of Management Development, Vol.36,No 1, pp.14 - 36. https://doi.org/10.1108/JMD-10-20140121ff.

Wang, X., Zhang, Y., Huang, Z., Hong, M., Chen, X., Wang, S., Meng, X. (2016). Assessing willingness to accept compensation for polluted farmlands: a contingent valuation method case study in northwest China. Environmental Earth Sciences, Vol.75, No 3, https://doi.org/10.1007/s12665-015-4872-y

Wolfe, P. (2019). Polyface farms pioneers permaculture, offers agritourism; The News- herald, Herald News. https://www.news-herald.com/lifestyle/travel/polyface-farms-pioneers-permaculture-offersagritourism/article_dc1f98a8-7e68-11e9-9a52-2fc293de85dchtml.

Worldwatch institute (2001) Vital signs 2002: The trends that are shaping our future. Appropriate Technology, 29 (2); Business Premium Collection pg. 33.

Xiong, K., \& Kong, F. (2017). The analysis of farmers' willingness to accept and its influencing factors for ecological compensation of Poyang Lake Wetland. Procedia Engineering, No.174, pp. 835-842. https://doi.org/10.1016/j.proeng.2017.01.230.

Xuhua, H., Spio-Kwofie, A., Udimal, T. B., \& Addai, M. (2018). Entrepreneurial innovation strategies: An option for small hotels' growth in Ghana. Journal of Global Entrepreneurship Research, Vol. 8, No 1. https://doi.org/10.1186/s40497-018-0116-4 